\title{
Analysis of the Fruit Value Chain of Two Priority Food Woody Species of Central Southern Niger, West Africa
}

\author{
Massaoudou Moussa1 ${ }^{*}$, Tougiani Abasse1, Habou Rabiou², Moussa Aboubacar ${ }^{1}$, \\ Larwanou Mahamane ${ }^{3}$
}

${ }^{1}$ Department of Natural Resources Management, National Institute for Agricultural Research (INRAN), Maradi, Niger

${ }^{2}$ University of Diffa, Diffa, Niger

${ }^{3}$ International Crops Research Institute for the Semi-Arid Tropics (ICRISAT), Niamey, Niger

Email: ^mmassaoudou13@gmail.com, abasse.tougiani@gmail.com, amoussa@gmail.com, rabiouhabou@yahoo.fr,

M.Larwanou@cgiar.org

How to cite this paper: Moussa, M., Abasse, T., Rabiou, H., Aboubacar, M., \& Mahamane, L. (2020). Analysis of the Fruit Value Chain of Two Priority Food Woody Species of Central Southern Niger, West Africa. Open Journal of Forestry, 10, 277-292. https://doi.org/10.4236/ojf.2020.103018

Received: April 11, 2020

Accepted: May 17, 2020

Published: May 20, 2020

Copyright $\odot 2020$ by author(s) and Scientific Research Publishing Inc. This work is licensed under the Creative Commons Attribution International License (CC BY 4.0).

http://creativecommons.org/licenses/by/4.0/

\begin{abstract}
Non-timber forest products provide important socio-economic services to different village and urban communities in West Africa. However, little is known about the links between the different actors and their contribution to the local or national economy. This study was conducted in central southern Niger and aimed to 1) identify and map the main actors in the value chain of Ziziphus mauritiana and Balanites aegyptiaca fruits; and 2) analyse the silvicultural and socio-economic aspects of fruit exploitation of these two species. Socio-economic surveys were conducted in four big villages in two main agroecological zones. Fruit exploitation of these two species affected 3044 people, with estimated 39 tonnes of $Z$. mauritiana and 27 tonnes of $B$. aegyptiaca fruit collected in 2017. The surveys revealed that the main actors were women (62.05\%), constituting the primary core of the actors of the value chain. Exploitation was mainly conducted in forests $(68.6 \%)$ or on farms (15.4\%) with no restrictions to access. Marketing of $Z$. mauritiana concerned fresh fruit (68.8\%) and fruit processed into biscuits (82.14\%), and that of $B$. aegyptiaca involved fruit (38.5\%) and oil extracted from seeds $(38.7 \%)$; the net margin was estimated at $71.71 \% \pm 21.59 \%$ for the first species and $50.31 \%$ $\pm 47.99 \%$ for the second. The income was mainly used for the needs of farmers' households. Links have been identified where consumers and processors supply seeds, after extracting the fruit pulp, to nurserymen for the production of plants for the villages or farms. This study reveals an important potential and opportunity for job creation and improved food and nutritional status of the vulnerable strata of rural communities in Niger. Improving the links between the various actors will establish a more sustainable promotion of the fruits of these two species.
\end{abstract}




\section{Keywords}

Balanites aegyptiaca, Ziziphus mauritiana, Value Chain, Non-Timber Forest Products, Food Security, Income, West Africa

\section{Introduction}

Non-timber forest products (NTFP) are of vital importance in the lives of rural communities in sub-Saharan Africa. FAO (1999) defines NTFP as products of "biological origin other than wood from forests, other wooded lands and trees outside the forest", although its definition remains debatable (Ahenkan \& Boon, 2011). Tree products include fruits, leaves, gum and resin, bark, flowers, seeds, latex, tannin, honey, etc. (FAO, 1999). They provide significant services, notably supply and cultural services, at local, regional, and international level and their products can be used for human and animal nutrition, pharmacopoeia, bioenergy production, cosmetics, wastewater treatment, fermentation of local products, etc. (Vieira et al., 2010; Melaku et al., 2014; Shackletona \& Pandey, 2014; Maisharou \& Lawanou, 2015). An increasing number of actors are lining up around the exploitation or production, transformation, marketing, and management of trees that generate valuable products. Value chains are established for these products to estimate the costs. The analysis of the NTFP value chain has emerged in recent years because these products are of importance at the local, regional, and international levels (Jensen, 2009; Sathre \& Gustavsson, 2009; Tieguhong et al., 2015; Ingram et al., 2017). This further complicates the sustainable management of forest resources.

Ziziphus mauritiana and Balanites aegyptiaca are two species from the families of Rhamnaceae and Zygophillacea, respectively (APG IV, 2016). They are native to arid and semi-arid areas of sub-Saharan Africa, and their fruits, roots, leaves, bark, and wood are widely used for nutritional, medicinal, energy, and cultural needs (Weber \& Sotelo Montes, 2010; Faye et al., 2011; Jamnadass et al., 2011; Sotelo Montes et al., 2013; Sagna et al., 2014). They have a wide distribution area, high production potential, and fruit diversity (Ouédraogo et al., 2006; Abasse et al., 2010; Sagna et al., 2014). They have also been cited among the priority species for domestication in agroforestry systems and cover the entire value chain (from production to fruit processing) of arid and semi-arid sub-Saharan Africa (ICRAF, 2009; Leakey et al., 2012). Recent studies in central southern Niger have revealed the significant potential of these two species as valuable resources for local communities, as the fruit of $B$. aegyptiaca is used for oil and almond extraction and the fruit of $Z$. mauritiana is utilized for production of biscuits (Habou et al., 2020). Synergy and a circular economy are being established between rural and urban areas for exploitation and promotion of the products of these two species. Despite the socio-economic value of these species to the local population, their exploitation remains unregulated and on per-need 
basis in all villages visited. Furthermore, many of the constraints weigh on the processing and marketing of their products. These constraints are of several orders, and can be, the disorganization of women in formal marketing structure, the absence of adequate fruit crushing equipment and oil press, the lack of publicity on products, fruit attacks by insects, etc. (the present study). Thus, it is important that these communities receive support from different stakeholders like NGOs, foresters and researchers to develop sustainable management of their own natural resources. This can be achieved first by a full analysis of the value chain related to the products and by-products of these two species, and by highlighting the links between the different actors (e.g. Jensen, 2009; Tieguhong et al., 2015; Ingram et al., 2017; Chogou et al., 2019). More specifically, this will strengthen actors' capacity to innovate and seek solutions to certain technical and institutional difficulties encountered in production, consumption, processing, and marketing to ensure sustainable management of agroforestry parklands (Ingram et al., 2017). In addition, knowledge about the economy of NTFP in general and that of $B$. aegyptiaca and $Z$. mauritiana is very limited in particular in Niger. These shortcomings hamper the sustainable governance of forest resources in Niger, especially in terms of the sector's contribution to the national gross domestic product when we know that the national development policy, in particular poverty reduction, food and nutritional security, fight against land degradation, and mitigation and adaptation to climate change rests essentially on the rural sector, in particular, the forestry sector. This study aims to fill all these gaps by 1) identifying and mapping the main actors in the fruit value chain of these two main priority species in the central southern region of Niger; and 2) by analysing the silvicultural and socio-economic aspects of the fruit exploitation of these two species.

\section{Methods}

\subsection{Study Zone}

The study area was divided into a strict Sahelian sector (ZS) and Sahelo-Sudanian sector (ZSS) (Figure 1). Climate of the Sahelian sector is characterized by a long dry season followed by a short rainy season. The dry season is divided into a cold dry season, which extends from November to February and whose average daily temperatures fluctuate between $10^{\circ} \mathrm{C}$ and $20^{\circ} \mathrm{C}$, and a hot dry season from March to May during which temperatures can reach $40^{\circ} \mathrm{C}$. In these areas, temperatures average between $27^{\circ} \mathrm{C}$ and $29^{\circ} \mathrm{C}$. The rainy season generally begins in June and ends in October. The average annual rainfall, calculated over the last 30 years, is $463 \pm 133 \mathrm{~mm}$. As for the Sahelo-Sudanian sector, the average rainfall over the last 8 years was $550 \pm 132 \mathrm{~mm}$. The average monthly temperature varies quite strongly from one season to another: it is around $21.9^{\circ} \mathrm{C}$ in January to $38.6^{\circ} \mathrm{C}$ in May; the minimums range from $13.6^{\circ} \mathrm{C}$ in January to $26.9^{\circ} \mathrm{C}$ in May, while the maximums vary from $30.2^{\circ} \mathrm{C}$ in January to $40.4^{\circ} \mathrm{C}$ in April. 


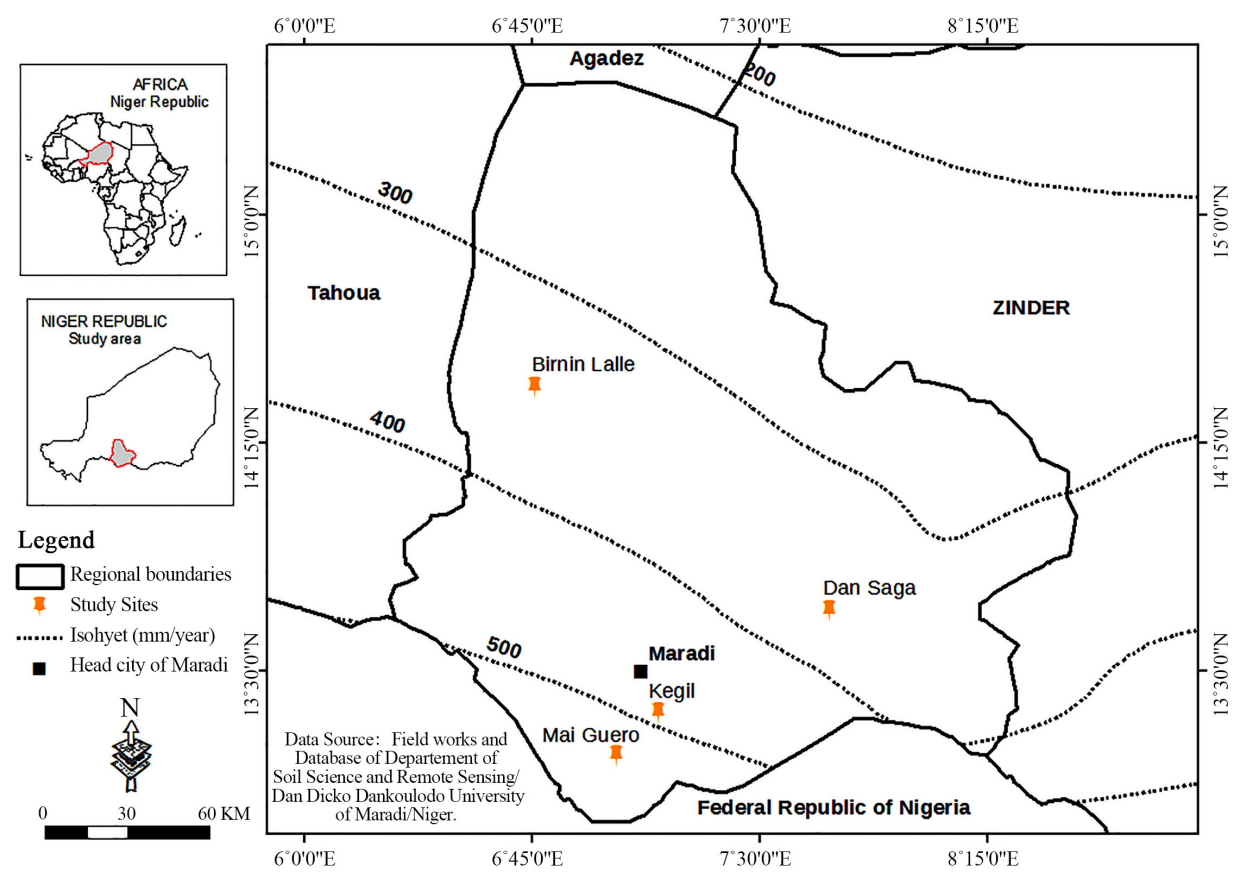

Figure 1. Location of study sites.

\subsection{Choice of Sites}

To conduct this study, literature was reviewed on the value chain of NTFP. An analysis of woody food species was carried out through village meetings between researchers, government officials, and resource peasants who are very familiar with the environment and village structure, and therefore, can help with the development and management of forest resources. This led to an initial selection of seven large central villages per agroecological zone. Exploration and maintenance visits with the population of each village enabled us to retain a total of two centrals villages per zone with the potential for woody food species that are highly valued by the locals. These are the villages of Birnin Lallé and Dan Saga in the ZS and Mai Guero and Keguil in the ZSS (Figure 1). All the villages located within a $5 \mathrm{~km}$ radius from the big villages were surveyed to take into account the heterogeneity of the sectors. A rapid exploration was then carried out to establish the exhaustive list of actors in the value chain of B. aegyptiaca and $Z$. mauritiana in each village. It emerged that each actor was interested in the products of these two species in each village (Table 1).

We used the following formula (1), proposed by Dagnelie (1998), to determine the sample of households to be surveyed per village.

$$
N=\frac{4 p(1-p)}{d^{2}}
$$

where $N$ is the number of people to be surveyed, $p$ is the proportion of actors in the fruit value chain of $B$. aegyptiaca and $Z$. mauritiana in each village, and $d$ is the margin of error, which was set to $5 \%$ for this study. This approach is widely used for establishing samples in social studies (Palm, 2002; Shaikh et al., 2012; 
Lean et al., 2014). Thus, the sample size was determined for each village (Table 2). Additional data were collected through interviews with transporters, wholesalers, and exporters located in the centre of the Maradi region. This approach allowed us to illustrate four types of frequented markets for the products of these two species. These were the markets within the same village or in surrounding villages markets (VM), departmental weekly markets (DWM), regional markets (RM), and the foreign market (FM) to Nigeria.

Table 1. Characteristics of the study sites.

\begin{tabular}{|c|c|c|c|c|c|c|}
\hline Zones & Sites & Longitude & Latitude & $\begin{array}{l}\text { Distance } \\
\text { from the } \\
\text { big city } \\
\text { (Maradi, } \\
\text { km) }\end{array}$ & $\begin{array}{l}\text { Estimated } \\
\text { number of } \\
\text { households }\end{array}$ & $\begin{array}{l}\text { Distribution of } \\
\text { two species }\end{array}$ \\
\hline \multirow[b]{2}{*}{ Sahelian } & $\begin{array}{l}\text { Dan } \\
\text { Saga }\end{array}$ & $\mathrm{N} 13^{\circ} 42^{\prime} 12^{\prime \prime}$ & $\mathrm{E} 007^{\circ} 44^{\prime} 37^{\prime \prime}$ & 99 & 743 & $\begin{array}{l}\text { Agroforestry } \\
\text { parklands }\end{array}$ \\
\hline & $\begin{array}{l}\text { Birnin } \\
\text { Lallé }\end{array}$ & $\mathrm{N} 14^{\circ} 25^{\prime} 53.3^{\prime \prime}$ & E006 ${ }^{\circ} 46^{\prime} 06.3^{\prime \prime}$ & 90 & 773 & $\begin{array}{l}\text { Agroforestry } \\
\text { parklands \& } \\
\text { grazing areas }\end{array}$ \\
\hline \multirow[b]{2}{*}{ Sahelo-Sudanian } & Kégil & N13 $21^{\prime} 33.8^{\prime \prime}$ & $\mathrm{E} 007^{\circ} 10^{\prime} 06.9^{\prime \prime}$ & 15 & 738 & $\begin{array}{c}\text { Agroforestry } \\
\text { parklands \& } \\
\text { classified forest } \\
\text { of Madarounfa } \\
\text { (830 ha) }\end{array}$ \\
\hline & $\begin{array}{c}\text { Mai } \\
\text { Guéro }\end{array}$ & $\mathrm{N} 13^{\circ} 13^{\prime} 10.7^{\prime \prime}$ & E007 $01^{\prime} 54^{\prime \prime}$ & 47 & 758 & $\begin{array}{c}\text { Agroforestry } \\
\text { parklands, } \\
\text { grazing areas \& } \\
\text { classified forest } \\
\text { of Baban Rafi } \\
(35,540 \mathrm{ha})\end{array}$ \\
\hline Total & 4 & - & - & - & 3,044 & 3 \\
\hline
\end{tabular}

Table 2. Distribution of people surveyed per village and per agroecological zone.

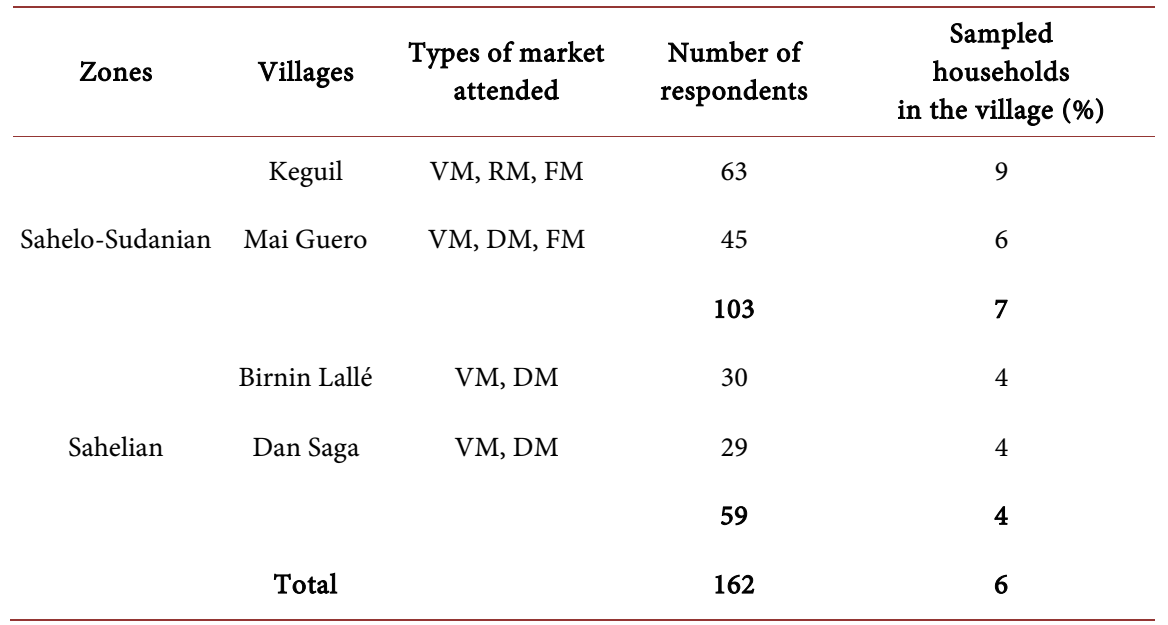

VM, surrounding villages markets; DWM, departmental weekly markets; RM, regional markets; FM, foreign market. 


\subsection{Data Collection}

The surveys were conducted at the individual level in the local language using semi-structured questionnaires from January to February 2017. They enabled collection of data on: socio-economic characteristics and the link between actors in the chain of value, exploitation and management of two species in the region, quantification of fruit exploited, cost analysis, description of the marketing circuit, etc. Field measurements were carried out to assess tree and production potential of the two species.

\subsection{Data Analysis}

The collected data was quantitatively processed with Excel spreadsheet and SPSS 22 software (IBM Corp., Armonk, NY, USA) and qualitatively processed with content analysis. Descriptive statistics (mean, standard deviation, frequency of citation) were performed. The frequency of citations from survey respondents for different variables was calculated using the following formula (2):

$$
F_{i}=\frac{n_{i}}{N} \times 10
$$

where $F_{\mathrm{i}}$ is the frequency of citation, $n_{\mathrm{i}}$ is the number of favourable citations for variable $i$, and $N$ is the total number of respondents. The amount of fruit collected by farmers was assessed in the field using the local measuring unit ("tiya"). The measurements were repeated with ripe fruit. On average, the local measurement corresponded to a coefficient k equal to $1.90 \mathrm{~kg}$ and $1.30 \mathrm{~kg}$ for $B$. aegyptiaca and $Z$. mauritiana, respectively.

The amount of fruit collected per tree was determined using the following formula (3):

$$
Q_{c}=Q_{m} \times k
$$

where $Q_{\mathrm{c}}$ is the quantity of fruit collected in kilograms, $Q_{\mathrm{m}}$ is the quantity of collected fruit expressed in the local measurement, and $k$ is the conversion coefficient from local measurement to kilogram. The gross product was calculated on the basis of the following formula (4):

$$
\mathrm{PB}=Q_{c} \times \mathrm{PU}
$$

where PU is the unit price of fruit. PU varies with the time of year; it is lower in the fruit harvesting season and higher in the non-fruiting period. For each activity, the costs were calculated using an approach similar to that of Ingram et al. (2017) and Nygren et al. (2006):

Operating costs, which include fixed costs and variable costs, were calculated with the following formulas $(5,6)$ :

$$
\begin{aligned}
\text { Fixed costs }= & \left.\sum \text { cost of material (bag, cup, etc. }\right) \\
+ & \text { cost of transport and miscellaneous costs }(\text { tax, insurance }) \\
& \text { Variable costs }=\sum \text { cost of labour and others }
\end{aligned}
$$

The net margin, which helps to assess the profitability of the operation, was 
calculated based on the following formula (7):

$$
\text { Net margin }=\text { Net profit } \times 100 / \mathrm{PB}
$$

To assess the relationship between the quantitative variables, we perform the Pearson correlation test at the significance level of $95 \%$.

\section{Results and Discussion}

\subsection{Value Chain Mapping}

\subsubsection{Socioeconomic Characteristics of the Actors}

The fruit value chains of $B$. aegyptiaca and $Z$. mauritiana are characterized by a number of actors, the main ones being collectors, processors, traders, and consumers (Figure 2), as well as the intermediaries, notably transporters. The first three actors comprised mainly women in the two agroecological zones of the Maradi region. The enhancement activity of the fruits of B. aegyptiaca and $Z$. mauritiana was secondary for all stakeholders and occurred just after the harvest of agricultural products, which was conducted from October to November. This could be explained by the fact that in ZS, during the same period, men are engaged in harvesting of Andropogon gayanus and Cyperus esculentus stems (Dan Saga), which are more lucrative activities and in certain cases require traveling between villages. In contrast, in ZSS, men are more oriented towards off-season crops, small inter- and intra-village trade, and exodus to Nigeria. Socioeconomic characteristics showed that the sample of actors covered by the survey was composed of housewives ( $99 \%$ and $100 \%$ in ZSS and ZS, respectively). These actors were dominated by the age groups between 30 and 40 years $(27.18 \%$ and $20.33 \%$ ) and 40 to 60 years (29.12\% and $25.42 \%$ in ZS and ZSS, respectively). The age groups less interested in these activities included young people and older women. This indicates that this activity reaches the most vulnerable sections of the villages. In fact, in both sectors, besides farming, women are occupied with daily housework and product collection, and the sale of NTFP created a source of occupation and generated income to the women. The valuation of the fruits of these two species was secular because a positive and significant correlation was found between the time spent in the farm and the age of the respondents in ZSS $\left(r_{1}=0.29 ; p=0.025\right)$ and in ZS $\left(r_{2}=0.24 ; p=0.014\right)$ for the two species. This also indicates that this activity is gaining new members in both zones. The correlation was higher in ZSS than in ZS, which may be attributed to the higher percentage of nomads in the latter. The fruits of these two species are consumed by both women and men (40\% of women and $60 \%$ of men in ZSS and $36 \%$ of women and $64 \%$ of men in ZS). Therefore, these major actors in the value chain are dissociated from certain NTFP for certain forest species (Belcher \& Kathrin, 2007; Jensen, 2009; Ingram et al., 2017).

\subsubsection{Value Chain Circuit}

The fruit exploitation of these two species is done by actors from the villages who collect the fruits in forest formations such as agroforestry parklands, classified forests, and grazing areas. Thereafter, other actors stand out in the value 


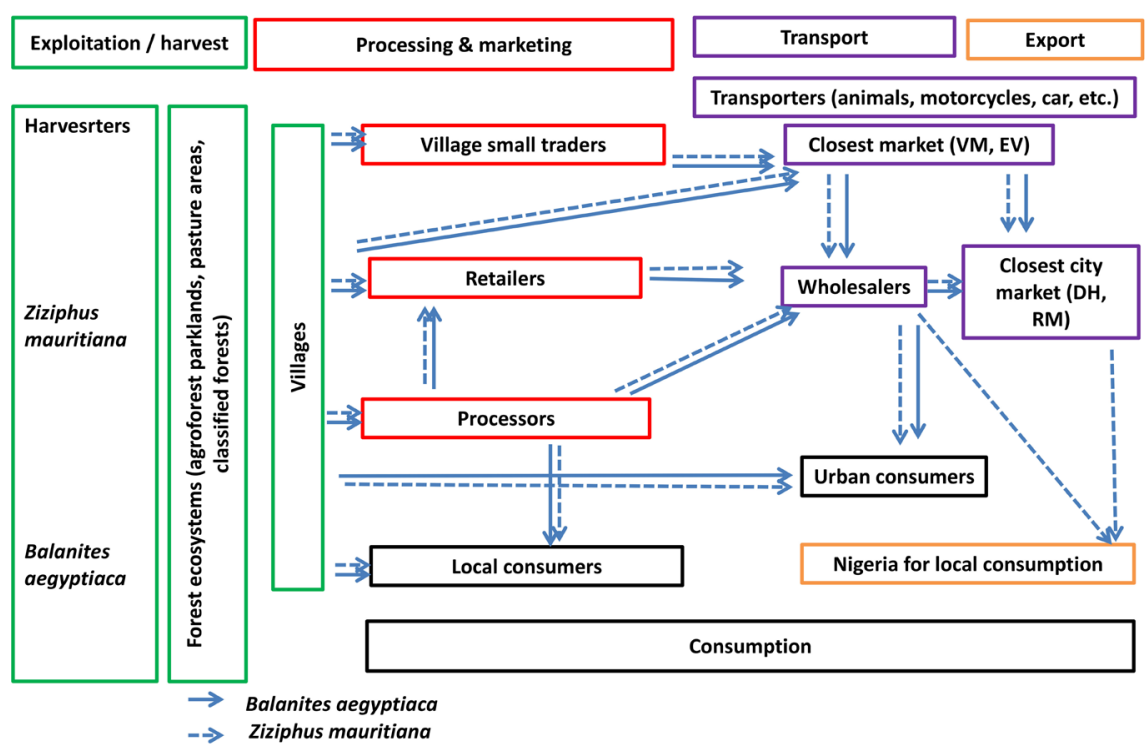

Figure 2. Actors and channels in the chain of Ziziphus mauritiana and Balanites aegyptiaca in the Maradi region.

chain, in particular processors, traders, and consumers. Under certain conditions, it was difficult to dissociate these actors in villages. Marketing affects a certain number of actors, sometimes from villages and other times from the nearest town (located 8 to $15 \mathrm{~km}$ from the villages, depending on the site), influencing both raw and processed products. Likewise, consumption modifies raw products as well as products processed in the village. When there is a large production, the products are sent to the market either in the village or the nearest town through rural transporters. This activity is carried out by wholesalers. Once exploited, the fruits are transported to the villages where they undergo several marketing channels before consumption. Hence, these fruits are either bought directly by consumers or sold to retailers or women processors. The women processors also get their supplies from village retailers to ensure sufficient quantities for processing. Processed products are either consumed directly in the village, or collected by traders (collectors), or purchased by wholesalers in the village (Figure 2). In turn, these actors supply the towns closest to the villages, notably the town of Maradi (Keguil), Dan Issa (Mai Guero), Dakoro (Birnin Lallé), and Aguié (Dan Saga). Only the products of $Z$. mauritiana are destined for export to Nigeria through wholesalers and collectors of city products. The marketed products, which included fruit and biscuits for $Z$. mauritiana, comprised $68.8 \%$ and $82.14 \%$ of the citations in the ZSS and ZS, respectively. For B. aegyptiaca, the marketed products were mainly fruit and oil, which covered $38.5 \%$ and $38.7 \%$ of the citations in the ZSS and ZS, respectively. Another type of product being marketed was identified in ZSS only, and it was represented by the nuts of B. aegyptiaca fruits.

\subsubsection{Fruit Exploitation Circuit}

The exploitation of the fruits of these two species was mainly done mainly in 
community areas such as grazing areas and classified forests (68.6\% and 59.1\% of citations for $Z$. mauritiana and B. aegyptiaca, respectively) located less than 1 $\mathrm{km}$ from the village of Keguil and $3 \mathrm{~km}$ from the village of Mai Guero in ZSS. However, we noted the presence of these two species in $7.8 \%$ ( $Z$. mauritiana) and $15.4 \%$ (B. aegyptiaca) of farms. In this, some producers consider the two species nuisance to farm work due to the presence of thorns scattered in fields after tree maintenance cutting. The presence of these two species in community ecosystems also justifies the decision of the locals not to conserve the trees on their own farms. In the ZS, these two species were frequently found in farms (53.6\% for Z. mauritiana and $67.6 \%$ for B. aegyptiaca) and in grazing areas (46.4\% and $22.6 \%$ for $Z$. mauritiana and $B$. aegyptiaca, respectively). These results contrast with those obtained in the ZS and could be explained by the absence of community forests. In addition, local populations tend to domesticate the two species on farms. Access to these resources is free in the two agroecological zones, except in Birnin Lallé where some producers (3.6\%) are fencing the trees of these species in their fields. In the ZS, producers have to travel short distances to collect the fruits of these two species because they are located near villages. The only difficulty they encountered is the need to wake up very early to get ahead of others and pick up the fallen fruit.

\subsection{Sylvicultural and Socio-Economic Aspects of Fruit Harvesting}

The tree density of these two species in the farms was very low at less than 10 trees per hectare (92.2\% for $Z$. mauritiana and $84.4 \%$ for B. aegyptiaca in ZSS; $82.1 \%$ for $Z$. mauritiana and $96.2 \%$ for $B$. aegyptiaca in ZS). The maintenance of both species included only ploughing and implementation of famer management natural regeneration (FMNR). $9.8 \%$ and $25 \%$ of farmers in ZSS and $39.3 \%$ and $29 \%$ of farmers in ZS applied the maintenance work to Z. mauritiana and B. aegyptiaca, respectively. The costs related to the maintenance of these species in the fields were difficult to determine because generally the owners rely on the rainy season. In contrast, for the FNMR, the producer used a workforce equivalent to 1000 FCFA per day. This thwarts the forest plantation where investments are more important (McEwan et al., 2020). The average annual quantity of fruit collected per farmer per year for $Z$. mauritiana was estimated at $123.69 \pm 112.05$ $\mathrm{kg}$ in ZSS and $137.10 \pm 120.05$ in ZS and that of B. aegyptiaca was estimated at $99.57 \pm 52.84 \mathrm{~kg}$ (in ZSS) and $77.73 \pm 46.81 \mathrm{~kg}$ (in ZS) (Figure 3). The quantity of harvested product was estimated at 39 tonnes for $Z$. mauritiana and 27 tonnes for B. aegyptiaca; of those, 19 and 20 tonnes of $Z$. mauritiana were collected in ZSS and ZS, respectively, and 17 and 15 tonnes of $B$. aegyptiaca were harvested in ZSS and ZS, respectively. The farmers were unable to assess the amount of fruit produced by a tree for each species due to the open nature of the farms. However, a B. aegyptiaca tree under optimal can produce more than $52 \mathrm{~kg} /$ year (Chapagain et al., 2009). As for $Z$. mauritiana, its production varies depending on ecotypes and environmental conditions (Arndt et al., 2001; Ouédraogo et al., 2006). 

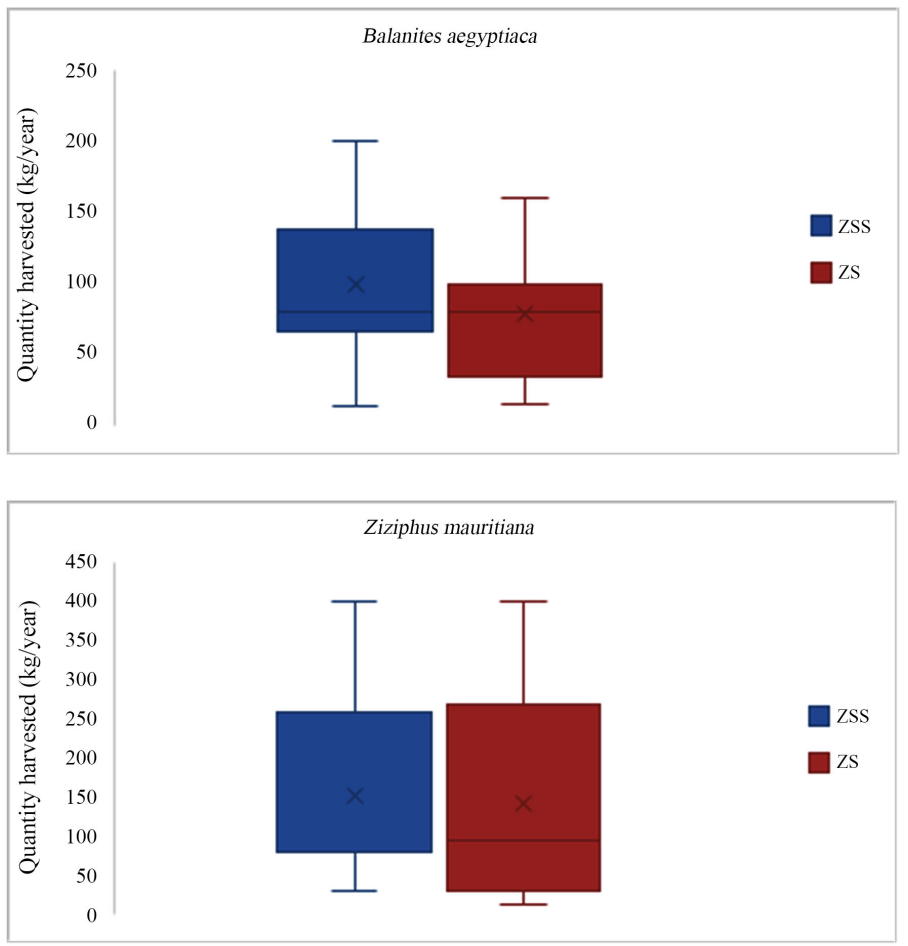

Figure 3. Quantity of fruit harvested per species and agroecological zone.

On average, B. aegyptiaca fruit was sold by farmers for $63 \pm 21$ FCFA per kilogram. The only expenses related to fruit harvesting included labour and the purchase of pickup equipment, which were estimated at $247 \pm 35$ FCFA and 825 \pm 323 FCFA, respectively, per operator. The total investment costs were $1571 \pm$ 331 FCFA to generate a gross product equal to $5718 \pm 3789$ CFA francs, with a net profit of $4147 \pm 3804$ CFA francs and a net margin of $50.31 \% \pm 47.99 \%$. The average price of Z. mauritiana fruit per kilogram was $84 \pm 22$ FCFA. The total investment costs were estimated at $2.036 \pm 805 \mathrm{FCFA}$ and the gross product was $14.970 \pm 13.583$ FCFA, which generated a net profit of $12.934 \pm 13.369$ FCFA and a net margin of $71.71 \% \pm 21.59 \%$. With regard to processed products, on average, the quantity of biscuits produced per processor was estimated at $220 \pm$ 109 units in the ZSS and $173 \pm 23$ units in the ZS; each unit was sold for 25 - 50 FCFA. The amount of oil produced by transformer per week was estimated at 3 $\pm 1 \mathrm{~L}$ (ZSS) and $2 \pm 1 \mathrm{~L}$ (ZS), and it was sold at an average price of $1.431 \pm 420$ FCFA per litre. These results indicated that fruit exploitation was beneficial to women. Part of the income from the sale of B. aegyptiaca fruit (32.79\% in ZS and $67.21 \%$ in ZSS) and that of $Z$. mauritiana fruit (37.29\% in ZS and $62.71 \%$ in ZSS) was used to meet basic household needs primarily related to health, education, clothing, and food. This contribution of NTFP to households was similar to that reported in other studies conducted in West Africa (Gustad et al., 2004; Shackleton et al., 2011; Gabou \& Maisharou, 2015; Maisharou \& Larwanou, 2015; Ingram et al., 2017). After harvest, $45.1 \%$ and $61.5 \%$ of $Z$. mauritiana and B. aegyptiaca fruits, respectively, in the ZSS were eaten unprocessed. Similarly, $71.4 \%$ of $Z$. mauritiana and $83.9 \%$ of $B$. aegyptiaca fruits were consumed unprocessed. 
The remaining B. aegyptiaca fruit was processed and consumed in the form of nuts (12.90\%), mixed with spinach (12.10\%) and pasta (44.35\%), or used for oil extraction (30.65\%). As for $Z$. mauritiana, we identified three forms of fruit consumption: as biscuits (49.39\%), mixed in porridge (17.07\%), and as pasta (33.54\%). These traditional forms of consumption of $Z$. mauritiana fruits are similar to those reported by studies in other communities in Africa (Nyanga et al., 2008), but other forms of nutritional and health use of this fruit have been also reported (Bhatia \& Mishra, 2010; Mishra et al., 2011; Delfanian et al., 2016). As for the fruit of B. aegyptiaca, its nuts and oil are utilized for human consumption (Aviara, Mamman, \& Umar, 2005; Al Ashaal et al., 2010) and as biofuel (Chapagain et al., 2009) with important physicochemical properties. All these products were consumed by men at $40.35 \%$ (ZSS) and $35.55 \%$ (ZS) and by women at $80.6 \%$ (ZSS) and $64.45 \%$ (ZS), indicating a considerable market for actors in the value chain of these two species. The most often cited sources of fruit exploitation were agroforestry parklands $(19.6 \%$ and $48.1 \%$ for $Z$. mauritiana and $B$. aegyptiaca, respectively) as well as grazing areas and classified forests (58.8\% and $40.4 \%$ for $Z$. mauritiana and B. aegyptiaca, respectively) in the ZSS. However, in the ZS, the agroforestry parklands $(42.9 \%$ and $80.6 \%$ for $Z$. mauritiana and $B$. aegyptiaca, respectively) represented the most cited supply source. Agroforestry parklands are community owned ecosystems in which logging is unorganized. Domestication of these two species for diverse needs of the local population has been investigated in other studies (Ouédraogo et al., 2006; Sotelo Montes et al., 2010; Sidibé et al., 2012), and non-seminal propagation methods should be considered to ensure successful regeneration of the two species in the studied areas after intensive fruit harvest (e.g. Danthu et al., 2004; Tchiagam et al., 2011).

\subsection{Value Chain Sustainability}

In the villages of Dan Saga (ZS) and Keguil (ZSS), after certain consumers and processors have extracted the pulp from the fruits of $Z$. mauritiana, the seeds are sold to private nurseries, NGOs et cetera for the production of seedlings. The plants produced are grafted with improved varieties of $Z$. mauritiana and sold in villages, that means it is necessary for the actors to establish a closer link between them. In contrast, the operator brings the fruits to consumers and processors, who in return can provide seeds to nurserymen, especially of the serviced parts of these resources. The latter supplies the plants to producers, NGOs and development organisations like project or government forestry agency for transplantation. To ensure the sustainability of resources and the value chain, these links need to be developed and extended to B. aegyptiaca trees as well as to many other valuable species. This is how the fruit harvest will respect ecologically tolerable thresholds (Avocèvou-Ayisso et al., 2009). To ensure the sale of B. aegyptiaca oil, Dan Saga village processors have established informal contracts with retail sellers in the most distant towns. In these contracts, the oil is collected and sold. The retail sellers then reimburse each woman in proportion to the quantity 
supplied and keep the profit. This contract does not work well because the retail sellers do not honor their commitment in all cases. Such kind of contract make it much more formal in the sense of "win-win", where all the actor's benefit, and can be extended to other valuable products and food stores in the region. Such reflections have been addressed by many studies, whose authors concluded that improving governance, knowledge of resources, the formal market and marketing channels can lead to the sustainable exploitation of NTFP (Avocèvou-Ayisso et al., 2009; Tieguhong et al., 2015; Wiersum et al., 2014; Ingram et al., 2017). To ensure the sustainability of the resources and the fruit value chain of these two species, we propose the following: 1) identify the distribution and anthropogenic forces at the individual and collective level that weigh on the resources of these two species; 2) ensure governance of natural resources, specifically concerted management techniques for the propagation of these species and rational fruit collection, fruit processing and product marketing; and 3) make more formal relationship and strengthen the links between the different actors.

\section{Conclusion}

The main actors in the fruit value chain of $Z$. mauritiana and B. aegyptiaca are essentially women of all age groups, with varying degrees of participation depending on the agroecological zone. The hard kernels of the chain were mainly collectors who played both the role of fruit processors and local product sellers. It should be noted that the transporters and wholesale traders, who represented important actors linking the villages and the urban and foreign consumers of the products, illustrated. The trees of these two species are most commonly found in community forest ecosystems. Consequently, their logging is unregulated due to unrestricted access to the trees. The annual quantity of exploited fruit varied widely depending on the operators. The fruit of $Z$. mauritiana was mostly processed into biscuits by local villagers, and those of $B$. aegyptiaca were extracted for oil and almonds, which were then offered in the local and foreign village markets and urban markets at increasing frequency. Very little investment was required along the chain, resulting in the net margins greater than $50 \%$ for both species. The income was mostly used for basic household needs. The links of the sustainable value chain were defined. The results presented in this study can be used to guide public policies for sustainable management of forest resources and fight against food insecurity and poverty in Niger and beyond, in areas occupied by the same species.

\section{Acknowledgements}

This work was supported by the Agropolis fondation [grant numbers 1507-143, 2017].

\section{Conflicts of Interest}

The authors declare no conflicts of interest regarding the publication of this paper. 


\section{References}

Abasse, T., Weber, J. C., Katkore, B., Boureima, M., Larwanou, M., \& Kalinganire, A. (2010). Morphological Variation in Balanites aegyptiaca Fruits and Seeds within and among Parkland Agroforests in Eastern Niger. Agroforestry Systems, 81, 57-66. https://doi.org/10.1007/s10457-010-9323-x

Ahenkan, A., \& Boon, E. (2011). Non-Timber Forest Products (NTFPs): Clearing the Confusion in Semantics. Journal of Human Ecology, 33, 1-9. https://doi.org/10.1080/09709274.2011.11906342

Al Ashaal, H. A., Farghaly, A. A., Abd El Aziz, M. M., \& Alid, A. M. (2010). Phytochemical Investigation and Medicinal Evaluation of Fixed Oil of Balanites aegyptiaca Fruits (Balantiaceae). Journal of Ethnopharmacology, 127, 495-501. https://doi.org/10.1016/j.jep.2009.10.007

APG IV (Angiosperm Phylogeny Group) (2016). An Update of the Angiosperm Phylogeny Group Classification for the Orders and Families of Flowering Plants: APG IV. Botanical Journal of the Linnean Society, 181, 1-20. https://doi.org/10.1111/boj.12385

Arndt, S. K., Clifford, S. C., \& Popp, M. (2001). Ziziphus a Multipurpose Fruit Tree for Arid Regions. In S. W. Breckle, M. Veste, \& W. Wucherer (Eds.), Sustainable Land Use in Deserts (pp. 388-399). Berlin, Heidelberg: Springer. https://doi.org/10.1007/978-3-642-59560-8_41

Aviara, N. A., Mamman, E., \& Umar, B. (2005). Some Physical Properties of Balanites Aegyptiaca Nuts. Biosystems Engineering, 92, 325-334.

https://doi.org/10.1016/j.biosystemseng.2005.07.011

Avocèvou-Ayisso, C., Sinsin, B., Adégbidi, A., Dossou, G., \& Van Damme, P. (2009). Sustainable Use of Non-Timber Forest Products: Impact of Fruit Harvesting on Pentadesma butyracea Regeneration and Financial Analysis of Its Products Trade in Benin. Forest Ecology and Management, 25, 1930-1938. https://doi.org/10.1016/j.foreco.2009.01.043

Belcher, B., \& Schreckenberg, K. (2007). Commercialisation of Non-Timber Forest Products: A Reality Check. Development Policy Review, 25, 355-377. https://doi.org/10.1111/j.1467-7679.2007.00374.x

Bhatia, A., \& Mishra, T. (2010). Hypoglycemic Activity of Ziziphus mauritiana Aqueous Ethanol Seed Extract in Alloxan-Induced Diabetic Mice. Pharmaceutical Biology, 48, 604-610. https://doi.org/10.3109/13880200903218935

Chapagain, B. P., Yehoshua, Y., \& Wiesman, Z. (2009). Desert Date (Balanites aegyptiaca) as an Arid-Lands Sustainable Bioresource for Biodiesel. Bioresource Technology, 100, 1221-1226. https://doi.org/10.1016/j.biortech.2008.09.005

Chogou, S. K., Assogba, R., Degbey, H., Abokini, E., \& Achigan-Dako, E. G. (2019). Market Structure and Performance of Watermelon (Citrullus lanatus) in Benin. Scientific African, 3, e00048. https://doi.org/10.1016/j.sciaf.2019.e00048

Dagnelie, P. (1998). Statistique théorique et appliquée. Tome 1: Statistique descriptive et bases de l'inférence statistique. De Boeck et Larcier, Bruxelles.

Danthu, P., Touré, M., Soloviev, P., \& Sagna P. (2004). Vegetative Propagation of Ziziphus mauritiana var. Gola by Micrografting and Its Potential for Dissemination in the Sahelian Zone. Agroforestry Systems, 60, 247-253. https://doi.org/10.1023/B:AGFO.0000024415.22907.bc

Delfanian, M., Kenari, R. E., \& Sahari, M. A. (2016). Utilization of Jujube Fruit (Ziziphus mauritiana Lam.) Extracts as Natural Antioxidants in Stability of Frying Oil. Interna- 
tional Journal of Food Properties, 19, 789-801.

https://doi.org/10.1080/10942912.2015.1043638

FAO (1999). FAO Forestry-Towards a Harmonised Definition of Non-Wood Forest Products. Unasylva, 198. Food and Agriculture Organisation.

Faye, M. D., Weber, J. C., Abasse, T. A., Bou-Reima, M., Larwanou, M., Bationo, A. B., Diallo, B. O., Sigué, H., Dakouo, J. M., Samaké, O., \& Diaité, D. S. (2011). Farmers' Preferences for Tree Functions and Species in the West African Sahel. Forests, Trees and Livelihoods, 20, 113-136. https://doi.org/10.1080/14728028.2011.9756702

Gabou, M. H., \& Maisharou, A. (2015). Management Practices/Techniques Commonly Used in Niger Republic, West Africa. In R. Lal, B. Singh, D. Mwaseba, D. Kraybill, D. Hansen, \& L. Eik (Eds.), Sustainable Intensification to Advance Food Security and Enhance Climate Resilience in Africa (pp. 305-314). Cham: Springer.

https://doi.org/10.1007/978-3-319-09360-4_16

Gustad, G., Dhillion, S. S., \& Sidibé, D. (2004). Local Use and Cultural and Economic Value of Products from Trees in the Parklands of the Municipality of Cinzana, Mali. Economic Botany, 58, 578-587. https://doi.org/10.1663/0013-0001(2004)058[0578:LUACAE]2.0.CO;2

Habou, R., Moussa, M., Abasse, T., Ali, M., Larwanou, M., \& Patrick, V. D. (2020). Structure et régénération des populations de Balanites aegyptiaca (L.) Del.et Ziziphus mauritiana Lam. suivant un gradient écologique dans la région de Maradi au Niger. Afrika Focus (Accepted).

ICRAF (2009). Renforcement des stratégies de subsistance à travers une utilisation et une gestion améliorée des parcs agroforestiers au Sahel (TAG 799, International Fund for Agricultural Development). Rapport Annuel 2008. Bamako, Mali: World Agroforestry Centre (ICRAF).

Ingram, V., Ewane, M., Ndumbe, L. N., \& Awono, A. (2017). Challenges to Governing Sustainable Forest Food: Irvingia spp. from Southern Cameroon. Forest Policy and Economics, 84, 29-37. https://doi.org/10.1016/j.forpol.2016.12.014

Jamnadass, R. H., Dawson, I. K., Franzel, S., Leakey, R. R. B., Mithofer, D., Akinnifesi, F. K., \& Tchoundjeu, Z. (2011). Improving Livelihoods and Nutrition in sub-Saharan Africa through the Promotion of Indigenous and Exotic Fruit Production in Smallholders' Agroforestry Systems: A Review. International Forestry Review, 13, 338-354. https://doi.org/10.1505/146554811798293836

Jensen, A. (2009). Valuation of Non-Timber Forest Products Value Chains. Forest Policy and Economics, 11, 34-41. https://doi.org/10.1016/j.forpol.2008.08.002

Leakey, R. R. B., Weber, J. C., Page, T., Cornelius, J. P., Akinnifesi, F. K., Roshetko, J. M., Tchoundjeu, Z., \& Jamnadass, R. (2012). Tree Domestication in Agroforestry: Progress in the Second Decade. In P. K. Nair, \& D. Garrity (Eds.), Agroforestry: The Future of Global Land Use (pp. 145-73). New York: Springer.

https://doi.org/10.1007/978-94-007-4676-3_11

Lean, W. L., Arnup, S., Danchin, M., \& Steer, A. C. (2014). Rapid Diagnostic Tests for Group A Streptococcal Pharyngitis: A Meta-Analysis. Pediatrics, 134, 771-781. https://doi.org/10.1542/peds.2014-1094

Maisharou, A., \& Larwanou, M. (2015). Market Potential of Non-Wood Forest Products in the Sahelian Countries. International Forestry Review, 17, 125-135.

https://doi.org/10.1505/146554815816007018

McEwan, A., Marchi, E., Spinelli, R., \& Brink, M. (2020). Past, Present and Future of Industrial Plantation Forestry and Implication on Future Timber Harvesting Technology. Journal of Forestry Research, 31, 339-351. https://doi.org/10.1007/s11676-019-01019-3 
Melaku, E., Ewnetu, Z., \& Teketay, D. (2014). Non-Timber Forest Products and Household Incomes in Bonga Forest Area, Southwestern Ethiopia. Journal of Forestry Research, 25, 215-223. https://doi.org/10.1007/s11676-014-0447-0

Mishra, T., Paice, A. G., \& Bhatia, A. (2011). Use of Seeds of Malay Apple (Ziziphus mauritiana) and Related Species in Health and Disease. In V. R. Preedy, R. R. Watson, \& V. B. Patel (Eds.), Nuts and Seeds in Health and Disease Prevention (pp. 733-739). London: Academic Press. https://doi.org/10.1016/B978-0-12-375688-6.10087-8

Nyanga, L. K., Nout, M. J. R., Gadaga, T. H., Boekhout, T., \& Zwietering, M. H. (2008). Traditional Processing of Masau Fruits (Ziziphus mauritiana) in Zimbabwe. Ecology of Food and Nutrition, 47, 95-107. https://doi.org/10.1080/03670240701702321

Nygren, A., Lacuna-Richman, C., Keinänen, K., \& Alsa, L. (2006). Ecological, Socio-Cultural, Economic and Political Factors Influencing the Contribution of Non-Timber Forest Products to Local Livelihoods: Case Studies from Honduras and the Philippines. Small-Scale Forestry, 5, 249-269.

Ouédraogo, S. J., Bayala, J., Dembél, C., Kaboré, A., Kaya, B., Niang, A., \& Somé, A. N. (2006). Establishing Jujube Trees in Sub-Saharan Africa: Response of Introduced and Local Cultivars to Rock Phosphate and Water Supply in Burkina Faso, West Africa. Agroforestry Systems, 68, 69-80. https://doi.org/10.1007/s10457-006-6843-5

Palm, R. (2002). Utilisation du bootstrap pour les problèmes statistiques liés à l'estimation des paramètres. Biotechnology, Agronomy, Society and Environment, 6, 143-153.

Sagna, M. B., Niang, K. S., Guisse, A., \& Goffner, D. (2014). Balanites aegyptiaca (L.) Delile: Geographical Distribution and Ethnobotanical Knowledge by Local Populations in the Ferlo (North Senegal). Biotechnology, Agronomy, Society and Environment, 18, 503-511.

Sathre, R., \& Gustavsson, L. (2009). Process-Based Analysis of Added Value in Forest Product Industries. Forest Policy and Economics, 11, 65-75. https://doi.org/10.1016/j.forpol.2008.09.003

Shackleton, S., Paumgarten, F., Kassa, H., Husselman, M., \& Zida, M. (2011). Opportunities for Enhancing Poor Women's Socioeconomic Empowerment in the Value Chains of three African Non-Timber Forest Products (NTFPs). International Forestry Review, 13, 136-151. https://doi.org/10.1505/146554811797406642

Shackletona, C. M., \& Pandey, A. K. (2014). Positioning Non-Timber Forest Products on the Development Agenda. Forest Policy and Economics, 38, 1-7.

https://doi.org/10.1016/j.forpol.2013.07.004

Shaikh, N. S., Swaminathan, N., \& Hooper, E. G. (2012). Accuracy and Precision of the Signs and Symptoms of Streptococcal Pharyngitis in Children: A Systematic Review. Journal of Pediatrics, 160, 487-493.e3. https://doi.org/10.1016/j.jpeds.2011.09.011

Sidibé, D., Sanou, H., Teklehaimanot, Z., Mahamadi, D., \& Koné, S. (2012). The Use of Mycorrhizal Inoculation in the Domestication of Ziziphus mauritiana and Tamarindus indica in Mali (West Africa). Agroforestry Systems, 85, 519-528.

https://doi.org/10.1007/s10457-012-9486-8

Sotelo Montes, C., Garcia, R. A., Da Silva, D. A., De Muñiz, G. I. B., \& Weber, J. C. (2010). Variation and Correlations in Traits of Prosopis africana and Balanites aegyptiaca in the West African Sahel: Implications for Tree Domestication Programs. For ests, Trees and Livelihoods, 19, 289-298.

https://doi.org/10.1080/14728028.2010.9752672

Sotelo Montes, C., Weber, J. C., Garcia, R. A., Silva, D. A., \& Muñiz, G. I. B. (2013). Variation in Wood Color among Natural Populations of Five Tree and Shrub Species in the Sahelian and Sudanian Ecozones of Mali. Canadian Journal of Forestry Research, 
43, 552-562. https://doi.org/10.1139/cjfr-2012-0510

Tchiagam, N. J. P., Ndzié, J. P., Bellefontaine, R., \& Mapongmetsem, P. M. (2011). Vegetative Propagation of Balanites aegyptiaca (L.) Del., Diospyros mespiliformis Hochst. ex. A. Rich and Sclerocarya birrea (A. Rich.) Hochst. in Northern Cameroon. Fruits, 66, 327-341. https://doi.org/10.1051/fruits/2011047

Tieguhong, J. C., Ingram, V., Mala, W. A., Ndoye, O., \& Grouwels, S. (2015). How Governance Impacts Non-Timber Forest Product Value Chains in Cameroon. Forest Policy and Economics, 61, 1-10. https://doi.org/10.1016/j.forpol.2015.08.003

Vieira, A. M. S., Vieira, M. F., Silva, G. F., Márcia, R., Márcia, F. K. T., \& Bergamasco, V. R. (2010). Use of Moringa oleifera Seed as a Natural Adsorbent for Wastewater Treatment. Water, Air, \& Soil Pollution, 206, 273-281.

https://doi.org/10.1007/s11270-009-0104-y

Weber, J. C., \& Sotelo Montes, C. (2010). Correlations and Clines in Tree Growth and Wood Density of Balanites aegyptiaca (L.) Delile Provenances in Niger. New Forests, 39, 39-49. https://doi.org/10.1007/s11056-009-9153-8

Wiersum, K. F., Ingram, V. J., \& Ros-Tonen, M. A. F. (2014). Governing Access to Resources and Markets in Non-Timber Forest Product Chains. Forests, Trees and Livelihoods, 23, 6-18. https://doi.org/10.1080/14728028.2013.868676 